\title{
EFFECTS OF PEER GROUP COUNSELLING AND SEX ON THE SELF -CONCEPT OF SECONDARY SCHOOL ADOLESCENTS: IMPLICATIONS FOR COUNSELLING.
}

\author{
AIHIE, Ose Ngozi PhD \\ School of Education, \\ College of Education, \\ Ekiadolor \\ email: oseaihie@yahoo.com
}

\begin{abstract}
The study investigated the efficacy of peer group counselling in enhancing the self-concept of secondary school adolescents in Benin City, Edo State, Nigeria. The influence of sex on the self-concept of these adolescents was also investigated. A pre-test, post test, control group design was employed in the study. Sixty-eight senior secondary school II students, randomly selected from three randomly selected public secondary schools (a boys' school, a girls' school and a coeducational school) participated in the study. A 40-item adolescent self concept scale (ASCS) adapted from Akinboye (1977) Adolescent Personal Data Inventory (APDI) was validated and used to measure the self-concept of the participants. A correlation coefficient $r=0.76$ was obtained using the test-retest reliability method to establish the stability of the instrument. Three hypotheses were formulated for the study and tested at .05 level of significance. Data collected were analysed using the Students' t-statistic and analysis of variance (ANOVA).The results of the study revealed that peer group counselling had a significant positive effect on the self-concept of the adolescents. There was no significant effect of sex on the self concept of the adolescents. Further analysis also revealed no interactive effect of treatment and sex on the self concept of the adolescents. The implications of these results for school counselling are exhaustively discussed and recommendations made.
\end{abstract}

Key words: peer group counselling, sex, self-concept, counselling

\section{Introduction}

Education provides people with prospects for the future. The school therefore provides services geared toward producing educationally, psychologically and socially well adjusted individuals who can compete favourably in the rapidly changing environment. The school counsellor occupies a central position in the education of the child as he or she liaises 
with all other persons concerned in the education and well being of the school child. The school counsellor provides counselling services that help the students cope with their studies and interpersonal relationships and also prepare them for life after leaving school.

Secondary school students are mainly adolescents and Santrock (2001) has described adolescence as a period of great challenge and confusion. During this period of transition from childhood to adulthood, adolescents exhibit maladaptive behaviours which hamper their academic achievement. Bracken (1996), among others, has expressed the view that many of these acts are manifestations of low self-concept. Undoubtedly, certain situations within and outside the school settings can impact negatively on a child's self concept level. Self concept is the affective or emotional aspect of the self which generally refers to how one feels about or how one values one's self (Huitt, 2004).

Self concept and achievement have been found to be dynamically interactive and reciprocal (Hamachek, 1998). They are mutually reinforcing such that a positive or negative change in one facilitates a commensurate change in the other. Reasoner (1992), Wilhite (1992) and Wiggins (1994) found positive relationship between self concept and academic achievement. This means that academic achievement can be improved when self concept is enhanced.

Sex is the biological dimension of being male or female while gender is the socio-cultural dimension (Santrock, 2001). Of all the aspects of a child's self concept, one of the most important is the discovery of the attitude toward his or her gender. Self-concept is developed not inherited. Social experiences influence the way boys and girls behave and this can affect self-concept development. Part of a youngster's growing up is the identification and knowledge of being a boy or a girl and this knowledge has specific implications for how the child feels about himself or herself and how others treat him or her.

Fontana (1981) and Obidigbo (2000) reported that girls have lower self-concept than boys. American Association of University Women (1992) reported that boys and girls begin school at the early years with equal self-concept but by the secondary school level, the self concept of girls is significantly lower than that of boys. Nwagwu and Nwaneri (2002), among others, however found no significant difference in the way Nigerian boys and girls perceive themselves. Having found that self concept is positively related to school success, its enhancement is of utmost importance. Brigman and Campbell (2003) have expressed the view that one of the most promising interventions for school counsellors 
interested in showing the impact of their services on students' achievement and behaviour, is group counselling. Evidence in literature about the use of peer group counselling among adolescents and young adults (Hatcher, Nadeau, Walsh, Reynolds, Galea \& Marze, 1994; Lane, 1999; and Tobias \& Myrick, 1999) clearly indicate its positive effects on the participants.

The essence of group counselling is that more persons are catered for at the same time. In the same way the use of peers as facilitators in group counselling could help the counsellor gain insight into the needs and problems of the group being served and it could also serve as a bridge for the gap between professionals and the diverse groups they serve. Generally, peer programmes build on the evidence that young people can easily get a lot of information from their peers. The similarity in age, status and interests also helps them relate well with one another. Peer-led programmes allow the direct involvement of young people in their own programmes (WHO/UNFPA, UNICEF, 1995).

\section{Problem of the Study}

The functions of the school counsellor are many. However, the number of practicing counsellors in the school is inadequate compared to the number of students to be served. The schools are large and the students are increasingly exposed to a lot of information (and misinformation), many of which impact negatively on their general well-being. The need to enhance the self-concept of these adolescents and keep them focused on achievement is crucial. To effectively reach out to the students for the realization of the goals of counselling, intervention methods that will extend the counsellors' influence are advocated. There is evidence in research that peers can be used to enhance the self concept of adolescents in schools (Egbochuku and Obiunu, 2006; Egbochuku and Aihie, 2009).

There may be much reported negativity in peer influence but there are many young persons who are dedicated to their own advancement and that of others. These ones, if trained can form the core of the peer counselling programme, the essential idea being that people are influenced and can be helped best by those who share their problems or conditions. There is however no evidence of the use of peer counsellors in our schools. If measures to extend the counsellors' influence are not adopted, many students would pass through the schools without benefiting much from the counselling services which are crucial to their development and future. 


\section{Purpose of the study}

The study is designed to:

- Assess the efficacy of peer group counselling in enhancing the self concept of secondary school adolescents,

- Find out the influence of sex on the self concept of adolescent.

\section{Hypotheses}

The three hypotheses formulated for the study are as follows:

1. There is no significant difference in the post-test self concept of adolescents in the experimental and control groups.

2. There is no significant difference in the self-concept of male and female adolescents at post-test.

3. There is no significant interactive effect of treatment by sex on the post-test self-concept of the adolescents.

\section{Methodology}

The research design is a pre-test, post- test, control group design. It was designed to investigate the effect of the manipulated (independent) variable, peer group counselling and the intervening variable, sex on the dependent variable, self concept.

The population for the study consisted of all the public senior secondary schools in Benin City, Edo state. They are about thirty-four public single sex and co-educational Senior Secondary Schools with population ranging from 5000 to 2,500 students. Stratified random sampling was used to select three schools from the strata - boys', girls', and co-educational schools.

The research instrument was administered to an average of three hundred students in the three schools selected. Students whose scores on the instrument represented low self-concept were selected and randomly assigned to the treatment and control groups. Ninety-three adolescents commenced the experiment. At post- test, due to attrition and improperly completed instruments, which were discarded, the sample consisted of sixty-eight (68) adolescent boys and girls. This number formed the sample for the data analyses in the study.

\section{Instrument}

The data for the study was collected by means of a 40- item Adolescent Self-concept Scale (ASCS) adapted from Akinboye's (1977) Adolescent Personal Data Inventory (APDI). The original version of the scale was made up of thirty (30) items. Some items on the scale were modified in language and ten (10) new items were added. The instrument consists of 
two sections, A and B. Section A seeks information on the respondents' sex, school type and family type. Section B consists of forty (40) sentences designed to tap the respondents' perception of self in academics, sociopersonal relationships and intellectual ability. Test-retest method was employed to establish the stability of the instrument and a correlation coefficient $\mathrm{r}=0.76$ was obtained.

\section{Procedure}

The research study took place in three phases. The pre-treatment phase involved pre-administration of the instrument on all participants and the random assignment of selected participants into the treatment and control groups. It also involved the training of peer counsellors to facilitate the peer group counselling encounter. The treatment phase, for the experimental group involved ten (10) weeks of peer group counselling during which the different experimental units met for one hour each week. The group counselling manuals were designed to enhance the self-concept of the participants and consisted of topics such as leadership skills, skills for effective study, good study habits, preparing for examinations, self awareness, self-esteem, self-worth, body image, self-acceptance and being yourself. The group counselling sessions were monitored by research assistants in the schools. The control group was taught Spoken English by the English teachers who acted as the research assistants in each of the schools, for the same period. The post treatment phase involved post administration of the research instrument on all participants, collection, collation and analysis of data gathered.

\section{Results}

The three hypotheses formulated for the study were tested at .05 level of significance. The results are presented below.

Hypothesis I

Table I. Means, standard deviation and t-test data on the effect of treatment on the post- test self- concept of the participants

\begin{tabular}{|l|c|c|c|c|c|}
\hline \multicolumn{1}{|c|}{ Treatment } & $\mathbf{N}$ & $\mathbf{X}$ & SD & $\begin{array}{c}\text { Mean } \\
\text { difference }\end{array}$ & t. \\
\cline { 1 - 4 } Peer group counselling & 34 & 164.71 & 13.45 & 31.89 & $* 6.58$ \\
\hline Control & 34 & 132.82 & 24.86 & \\
\hline
\end{tabular}


The results on Table 1 reveal a mean difference of 31.89 between the post-test self- concept scores of participants in favour of the peer counselling group. Analysis of the data shows that the calculated $t$-value of 6.58 is greater than the critical t-value of 1.96 with $\mathrm{df}=66$ and alpha level of .05.The null hypothesis is therefore rejected.

Hypothesis II

Table II. Means, standard deviation and t-test data on the effects of sex on the post- test, self- concept of participants

\begin{tabular}{|c|c|c|c|c|c|}
\hline Sex & $\mathbf{N}$ & $\mathbf{X}$ & SD & $\begin{array}{c}\text { Mean } \\
\text { Difference }\end{array}$ & t. \\
\hline Female & 30 & 149.37 & 26.62 & 1.08 & \multirow{2}{*}{$0.17 * *$} \\
\hline Male & 38 & 148.29 & 24.94 & \\
\hline \multicolumn{7}{|c|}{ not significant at $\mathrm{P}<.05$} \\
\hline
\end{tabular}

The analysis of data shown on Table II reveals that the calculated tvalue of 0.17 is less than the critical t-value of 1.96 with degree of freedom, 66 and alpha level, of .05. The mean difference of 1.08 was therefore not significant at $\mathrm{p}>.05$. The null hypothesis is therefore upheld. Sex has no effect on the post test self-concept of the participants.

Hypothesis III

Table III. Summary of ANOVA table of treatment by sex with post test scores as dependent variables

\begin{tabular}{|c|c|c|c|l|l|}
\hline Source & $\begin{array}{l}\text { Type III sum of } \\
\text { Squares }\end{array}$ & DF & Mean Square & F & Sign \\
\hline Treatment & 13254.40 & 1 & 14254.40 & $34.222^{*}$ & .000 \\
\hline Sex & 43.45 & 1 & 43.45 & .104 & .748 \\
\hline $\begin{array}{c}\text { Treatment } \\
\text { X sex }\end{array}$ & 23.67 & 1 & 23.67 & .057 & .812 \\
\hline Error & 24991.167 & 60 & 416.52 & & \\
\hline Total & 1548.550 & & & & \\
\hline
\end{tabular}

*Significant at $\mathrm{P}<.05$

The results on Table III indicate no interactive effect of treatment by sex on self- concept scores. The calculated F - value of $0.57, \mathrm{df}-(1,60), \mathrm{P}<$ 05 was not significant. The null hypothesis was therefore upheld that there is no interactive effect of treatment by sex on participants' self concept. 


\section{Discussion}

The findings of this study indicate that peer group counselling has a significant positive effect on the self concept of adolescents. The participants in peer counselling scored significantly higher than those in the control group in self- concept at post test. These findings lend credence to the assertion made by Hoffman and Warner (1976) and Divers - Starnes (1991), among others, that paraprofessionals, particularly peers can be as effective as professionals in counselling when given the required training. The findings also corroborate those of Jeffery and Reynolds (1994), Lane (1997), and Tobias \& Myrick (1999), who reported positive effects of peer group counselling on the participants. Children have certain advantages over adults in helping their peers. They understand their problems better because they are cognitively closer and so the peer counsellor can present issues in terms the group members will understand better. Cohen (1989) had noted that similarity between model and learner increases the influence of modelling. In the present study, the adolescents had the opportunity of being models to their peers as they facilitated the group counselling sessions and this enhanced the self concept of the participants significantly.

The findings also indicate no significant effect of sex on the self concept of the participants. These findings are at variance with the findings of Fontana (1981) and Obidigbo (2002) who reported that girls have lower self-concept than boys. The present findings also do not agree with the assertion made by the American Association of University Women (1994) that at the secondary school level, the self- concept of girls is significantly lower than that of boys. They however support the report of Nwagwu and Nwaneri (2002), whose findings indicated no significant difference in the way Nigerian boys and girls perceive themselves.

The findings indicate that societal constraints, and internal conflicts which Richard (1975) reported as inhibiting females' development of selfconcept, are losing their effects. A possible explanation for this is that in the last few decades, to a large extent there have been diversification of societal relations, careers, and roles such that the distinction between jobs for males and females is becoming hazy. Osareren and Ogunleye (2009) reported that both males and females in some non-traditional professions investigated, perceived their ability to carry out their jobs the same way. This high perception of ability is indicative of positive self concept. Models exist for both sexes in all spheres of life encouraging high aspiration level. 
The United Nation Population Fund (UNFPA) and other international organizations, in collaboration with the Nigerian Government and non-governmental organizations have been running programmes that promote gender equality and equity, encouraging Nigerian adolescents to perceive themselves positively, irrespective of sex, and other factors. That there was no significant interactive effect of treatment by sex goes to buttress the assertion that peer group counselling is an effective means of enhancing self concept among adolescents irrespective of sex.

\section{Implications for counselling:}

The findings have implications for counselling. The school counsellor could extend his or her effectiveness through the use of trained adolescents. The peer counsellors benefit from the specialized human relations, training and the opportunity to help others and this also contributes to their own personal growth and development. The development of peer counsellors may as well be the answer to people growing closer together rather than apart because the community can benefit from the positive image of the adolescents.

\section{Conclusion}

Based on the findings, it can be concluded that peer group counselling is an effective means of enhancing self-concept in adolescents. The effectiveness of peer group counselling in enhancing self concept does not depend on the sex of the adolescent. Peer group counselling has many advantages for all involved. The services are expanded and cost reduced because the professional counsellor would have time for other duties

\section{Recommendations}

Peer group counselling should be integrated into the school counselling programme and used on a regular basis. The counsellor could place adverts on the notice boards or announce on the assembly ground for peer counsellor trainees, stating the vital qualifications. The involvement of the students in the counselling process will have a positive effect on the students' interest in the school counselling programme.

\section{References}

Akinboye, J. O. (1977). Adolescent Personal Data Inventory APDI, Ibadan: Maritime Printers' Psychological Publications. 
American Association of University Women (1992). How Schools shortchange girls: A study of major findings on girls and_education. Washington D. C: Authors.

Bracken, B. A. (Ed) (1996). The hand book of self-concepts;_Development, Social and Clinical consideration. John Wiley and sons. Retrieved Oct 2004 from. http://www.userglobanet.co.uk/ebdsstudy/strategy/esteem . htl.

Brigman G \& Campbell. C. (2003). Helping students improve academic achievement and school success behaviour. Professional School Counselling 7 (2): 91-98; American School Counsellors Association

Divers-Starne, A.C. (1991). Assessing the effectiveness of an inner-city high school peer-counselling programme. Urban education 26, 269 284.

Egbochuku, E.O. \&Aihie O.N. (2009). Peer group counselling and school influence on adolescents' self-concept. Journal of_Instructional Psychology 36(1), 3-12.

Fontana, D. (1981). Psychology for teachers. London: British Psychological Society and Macmillan Publishers Ltd

Hamachek, D (1998). Self-concept and school achievement: Interaction dynamics and a tool for assessing the self concept component. Journal of Counselling and development, 73 (4), 419 - 425

Hatcher, S., Nadeau, M. Walsh, L, Reynolds, M, Galea. J. \& Marz, K (1994). The teaching of empathy for high school and college students, testing Rogerian method with the international reactivity index. Adolescence 29, 951-974.

Hoffman, A. M \& R. M. Warner (1976). Paraprofessionals' effectiveness. Personnel and guidance Journal_54(10), $494-497$.

Huitt, W. (2004). Self-concept and self- esteem. Educational Psychology interactive. Valdosta, G.A.. Valdosta State University. Retrieved Oct. 2004 from Http://chiron.valdosta. edu/whitt/co/col1/regsys/ self.html

Lane, C. (1997). Peer education hopes and realities - the West African Youth initiative. Presented at a John Hopkins_University/.CEDPA Symposium "the young and the_restless". Washington D.C, April 1997.

Nwagwu, H\& Nwaneri, C. (2002). The demographic differences in adolescent self-concept. Nigerian Journal of clinical and_counselling psychology 8 (2), $44-66$

Obidigbo, G.C (2002). The relationship between self concept and academic performances of Nigeria students, African_Journal on line: IFE Psychologia 10(2), 20 - 27. 
Reasoner, R.W (1992). Self esteem Resources National Association for self esteem.

Santrock, J. W. (2001). Educational Psychology New York: Mc GrawHill Book.

Tobias, A. K. \& Myrick R. D (1999). A peer- facilitator led interaction with middle school problem behaviour students. Professional School Counselling (5), 1, 27 - 33

UNICEF (2001). Children and Women's right in Nigeria: A wake-up call situation assessment and analysis. Edited by Hodge. Abuja: National Population Commission and UNICEF.

World Health Organization/United Nations Population Fund/United Nations Children's Fund (WHO/UNFPA/UNICEF) (1995). Programming for adolescent health. Discussion paper prepared for the WHO/UNFPA/UNICEF study group on programming for adolescents' health. 29. Nov - 4 Dec. 1995, Saillon, Switzerland.

Wiggins, T A (1994). The Relationship of self esteem to grades and achievement scores and other factors critical to school success. The School Counsellor. 41 (4), $234-244$.

Wilhite, S. C. (1992). Self concept of academic ability, self assessment of memory ability, academic aptitude, and study activities, as predictors of College course achievement. Report Research US Pennsylvania. 